\title{
Pronunciation Pedagogy and Intelligibility Issues in Language Acquisition
}

\author{
Manyasi N. Beatrice ${ }^{1, *}$ \\ ${ }^{1}$ School of Education, Maasai Mara University, P.0. Box 861- 20500, Narok, Kenya \\ *Correspondence: School of Education, Maasai Mara University, P.0. Box 861- 20500, Narok, Kenya. Tel: \\ 254-721-883-793. E-mail: beatymanyasi@gmail.com
}

Received: November 20, 2019

Accepted: December 20, 2019 Online Published: January 11, 2020

doi:10.5430/ijelt.v7n1p24

URL: https://doi.org/10.5430/ijelt.v7n1p24

\begin{abstract}
Language teachers' knowledge of pronunciation pedagogy affects their classroom practice. The study sought to find out language approaches used to teach pronunciation and to establish how teachers' mastery of pronunciation facilitate the acquisition of sounds by learners. The findings revealed that teachers of English had challenges when teaching pronunciation hindering mastery of English sounds by learners. Some of their pronunciation was not comprehensible distorting meaning. They used imitation, phonetic transcriptions, minimal pair drills and sentence drills to teach pronunciation. It was established that some of them had pronunciation difficulties affecting the intelligibility or comprehensibility of what they were communicating about. Learners do not have to achieve native like pronunciation but they should surpass the threshold level to ensure that their pronunciation does not distort the meaning of what they communicate. When a teacher who is meant to be a role model and source of input for learners uses incomprehensible pronunciation distorting meaning, it is a significant setback to English Language Teaching (ELT). There is need to reassess policies concerning who should be trained to teach English as a Second Language.
\end{abstract}

Keywords: pronunciation pedagogy, intelligibility issues, language acquisition, English Language Teaching

\section{Introduction}

Mastery of language, particularly English, which is a second language in Kenya, is a fundamental life skill that learners need to acquire and perfect at secondary school level. The teaching of English Language in Kenya adopts an integrated approach. The teaching of the four language skills: listening, speaking, reading and writing, plus the subsidiary skills of grammar and punctuation are done using the integrated approach. The Integrated English Language course is designed to ensure that listening and speaking skills are taught through comprehensions, poems, conversations or sentences to be read aloud (K.I.E., 2002). Oral narratives taught under these skills constitute the listening comprehension passages and are only found in the teachers' guide books. The teacher is therefore expected to read the oral narratives aloud as the students listen. Correct pronunciation is fundamental for the learners to get the right meaning of what is read. Other English language sounds to be taught are integrated in literary materials such as poems and passages. The teacher is expected to read some parts aloud to act as a role model to the learners. Therefore, teachers' knowledge of pronunciation pedagogy is essential.

English language was introduced to Kenyans when the British colonized the country. At the time of colonization, Swahili had already been established as a trade language in most parts of East African coast. Both languages, English and Kiswahili, are official languages in Kenya. English enjoys a greater prestige as it serves more functions than Kiswahili. It is used for administration, business, diplomacy, legal, education and media among other functions as a lingua franca. It is the medium of instruction in schools from grade four onwards. Kenyans mainly acquire English through formal education hence knowledge of the language is associated with literacy. Passing well in the subject is a prerequisite for admission to competitive university and middle level courses. It is therefore a policy in Education that English is a compulsory subject from grade one to secondary schools in Kenya. Those who pursue other careers in colleges and universities learn through English (KIE, 2002). Kenya has over forty-two indigenous languages hence errors of first language transfer are evident in English language use at the levels of phonology, grammar, lexicon and discourse. Being a second language primarily acquired through formal education, the study sought to establish 
teachers' mastery of English sounds and how effective they were as role models to learners using the following Research Questions:

i. Which language approaches were used to teach pronunciation?

ii. How did teachers' mastery of pronunciation facilitate acquisition of English language sounds by learners?

\section{Literature Review}

\subsection{Language as Communication}

The main purpose of language is communication. Pedagogy in education involves the entire process a teacher goes through from instructional planning, classroom practice to evaluation. In this paper, pronunciation pedagogy has been operationalized to mean approaches for teaching pronunciation and how teachers' mastery of pronunciation of the English sounds facilitate acquisition of the sounds by learners to foster comprehensibility in communication. Language Teaching based on the Communicative approach has clearly defined set of classroom practices (Nunan, 1991) which are:

- an emphasis on learning to communicate through interaction in the target language.

- use of authentic texts in the learning setting.

- learners focusing both on the target language and on the language learning process.

- an enrichment of the learner's own personal experiences as essential contributing elements to classroom learning.

- encouraging language activities outside the classroom to expand on the learner's vocabulary.

Language Educators argue that Communicative Language Teaching is quite effective in facilitating language acquisition as it encourages communicating in the target language both in the classroom and outside the classroom. An attempt to link classroom language learning with Communicative Language Teaching requires negotiation and cooperation among learners, fluency-based activities that encourage learners to develop their confidence, role-plays in which students practice and develop language functions, as well as the use of grammar and pronunciation activities (Richards and Rodgers, 2001). Classroom activities used in communicative language teaching include: role-play, interviews, games, dialogue, surveys, pair-work among others. To encourage parental involvement in learning, students take occasional grammar quizzes, or prepare at home using non-communicative drills.

\subsection{Approaches for Teaching Pronunciation}

\subsubsection{An Analytic - Linguistic Approach}

As the name suggests, the approach uses phonetic alphabet, articulator images, charts of the vocal devices, contrastive data, and other aids to complement listening, simulation, and production. It explicitly focuses attention on the sounds and rhythms of the target language. Pronunciation is taught by students imitating a role model, the teacher, or a recording (Cele-Murcia, 2007).

\subsubsection{The Natural Approach}

The approach is based on the theories of first language acquisition. Children initially focus on listening without pressure to speak giving them the opportunity to internalize the target sound system, similarly, learners of a second language need not be rushed to speak but listen at the initial stage. When children do speak later on, their pronunciation is usually good despite the fact that they never get involved in explicit pronunciation instruction (Richards and Rodgers, 2001). The natural approach should be applied to language teaching. Teachers should undergo solid training in phonetics and theories of first and second language acquisition, to act as role models in pronunciation pedagogy and apply how children acquire their first language in facilitating the target language development. Some of the activities for facilitating pronunciation pedagogy are: imitating sound recordings, making use of information from phonetics, such as a visual transcription system or charts that demonstrate the articulation of sounds. The teacher may also opt to use a technique derived from the notion of contrast in structural linguistics commonly referred to as the minimal pair drill. They use words that differ by a single sound in the same position. The language educator can use

Word drills or Sentence drills as illustrated in the next section.

Word drills 


$\begin{aligned} \text { feet } & \text { fit } \\ \text { sheep } & \text { ship } \\ \text { beat } & \text { bit } \\ \text { lead } & \text { lid } \\ \text { green } & \text { grin }\end{aligned}$

Sentence drills

Sentence drills use either syntagmatic drills or paradigmatic drills.

Syntagmatic drills mean contrast within a sentence such as:

The feet cannot fit in the shoes.

Did you at least get the list?

Paradigmatic drills mean contrast across two sentences such as:

Don't slip on the floor. (It's wet.)

Don't sleep on the floor. (It's cold.)

\subsubsection{The Communicative Approach}

Language educators argue that since the main goal of language is communication, using language to communicate should be fundamental in all classroom activities. The focus on language as communication brings renewed urgency to the teaching of pronunciation, since both pragmatic and circumstantial evidence indicates that there is a threshold level of pronunciation for non- native speakers of English (in this paper it is guided by intelligibility); if they fall below the threshold level, they will have oral communication problems no matter how excellent and extensive their control of English grammar and vocabulary might be. There are groups of English language learners whose oral communication need a high level of Intelligibility and therefore require special assistance with pronunciation such as: International business people and envoys who need to use English as their working lingua franca, refugees in immigration and vocational training programs wishing to transfer to English speaking countries, Teachers of English who are not native speakers and are expected to serve as role models and source of input for their students, People in non-English speaking countries working as tour guides, waiters and hotel Personnel who use English for dealing with visitors who do not speak their local languages. The goal of teaching pronunciation to such learners is not to make them sound like native speakers of English but to enable them to surpass the threshold level so that their Pronunciation does not distort their intended meaning as they communicate in the language. Having established that intelligible pronunciation is necessary for oral communication, teachers of English need the required threshold to be effective in pronunciation pedagogy.

\section{Methodology}

The study used the qualitative research paradigm hence focusing on small samples, investigating in details (Jwan and Ong'ondo, 2011). The paradigm enabled the researcher to gather in-depth understanding of language approaches used to teach pronunciation to facilitate mastery of English sounds and to establish how teachers' mastery of pronunciation facilitate acquisition of the sounds by learners considering intelligibility issues in language.

Observation of classroom teaching and learning activities was done hence the researcher found out the reality as concerns pronunciation pedagogy and intelligibility issues in language acquisition. Ethnography method was used during the study. It emphasized on investigating reality in language learning activities in the classroom contexts to facilitate acquisition of appropriate pronunciation. It involves a researcher participating in observing, listening, asking questions through formal and informal interviews (Hammersley and Artkinson, 2007). The study used the selective intermittent time mode. It is a very flexible approach; the frequency of the researcher visiting the schools was determined by the teaching of the relevant language skills under study (Pole and Morrison, 2003). The researcher made prior arrangements with the teachers based on their instructional planning to only visit the schools when they were teaching pronunciation. Qualitative paradigm uses non-probability sampling. The study sought to create knowledge by understanding the pronunciation pedagogy in depth. (Cohen, 2007; Lichtman, 2006). The researcher therefore used purposive sampling to select thirty-two trained teachers of English. Teachers Service Commission return forms were used to select schools with the greatest number of trained teachers of English and literature. Setting being important in qualitative studies, one national school, extra county and two county schools were selected to vary setting then teachers 
in those schools formed the sample size of thirty-two teachers.

To ensure conformity to research ethics, the researcher requested the participants' consent before recording interviews. There was no inducement of participants to contribute in the study. Anonymity of the schools and teachers was guaranteed. Yin (2009) reports that qualitative methodology uses words in reporting findings, not statistics. After generating data, it was analyzed qualitatively and reported in narration according to emerging themes relevant to the research questions. Qualitative researchers encourage naturalistic generalizations where likeness of settings or cases is a key factor. Findings can be generalized to other situations that are comparable with the ones in the study (Stake, 2005). The study had a number of similarities revealed by the generated data. All schools had a common curriculum, same recommended course books to be used, a similar teaching and assessment syllabus and similar Teacher Education Programs. Issues discussed are of value to policy makers and other researchers.

\section{Findings and Discussion}

\subsection{Approaches Used to Teach Pronunciation}

\subsubsection{The Communicative Approach}

Teachers used The Communicative Approach when teaching English. It was the central language in all classroom activities and communication. As discussed earlier, such an approach focuses on language as communication (Richards and Rodgers, 2001), hence making it necessary to teach pronunciation to deal with errors that may affect the comprehensibility of what is communicated. One of the features of the communicative approach is using realistic texts when learning a target language to facilitate language acquisition. Based on this feature, teachers used oral narratives, comprehension passages and poems as sources of their pronunciation teaching and learning activities.

They also used Integrated Language Teaching Approach, incorporating both the receptive and productive language skills besides integrating language and literature. Students were involved in activities such as; writing words that had similar pronunciation with some in the listening materials using oral narratives, comprehension passages and poems. Oral narratives were read by the teacher aloud as students listened. The teacher read aloud some parts of the poems and passages to act as a role model to learners in pronouncing certain sounds.

\subsubsection{Analytic Linguistic Approach}

Teachers used phonetic transcription as well as reading phonetically transcribed texts as students imitated them. The transcription targeted different consonant and vowel sounds as per the curriculum. However, some teachers had challenges when pronouncing some consonant sounds depending on their first language. It resulted in variations in pronunciation. For example, the following variations were noted when pronouncing the definite article 'the.'

Table 1. Variations in Pronouncing 'the'

\begin{tabular}{cc}
\hline English article & Teachers varied pronunciations \\
\hline & $\mathrm{Te}$ \\
The & Tse \\
& $\mathrm{De}$ \\
\hline
\end{tabular}

The variations depended on whether the teachers' first language used voiced sounds, voiceless sounds or both. In some cases, there was a mismatch between the transcribed word and the teacher's pronunciation.

\subsubsection{Minimal Pair Drills were Used by Teachers}

The aim was to help students distinguish between similar and problematic sounds in the target language through listening discrimination and spoken practice. Teachers used word level drills and sentence level drills. Students listened to the teacher provided model and repeated the sounds that were being taught. The technique should be enhanced by the use of tape recordings, and video recordings (Cele-Murcia, 2007). None of the teachers had the teaching and learning resources. Some of the word level drills used were: 


$\begin{array}{ll}\text { shell } & \text { sell } \\ \text { shave } & \text { save } \\ \text { she } & \text { see } \\ \text { shame } & \text { same } \\ \text { ship } & \text { sip } \\ \text { shoot } & \text { soot } \\ \text { shoe } & \text { sue } \\ \text { shop } & \text { soap } \\ \text { sheet } & \text { sit } \\ \text { show } & \text { sow } \\ \text { peak } & \text { pick } \\ \text { leave } & \text { live } \\ \text { least } & \text { list } \\ \text { seat } & \text { sit }\end{array}$

They also used sentence- level drills; both paradigmatic and syntagmatic.

\subsection{Teachers' Mastery of Pronunciation to Facilitate Acquisition of the Sounds by Learners}

Classroom observation during English language teaching was used to establish whether teacher's mastery of pronunciation facilitate learners' acquisition of English sounds. The teachers Pronunciation challenges were as presented in Tables 2.

Table 2. Teachers Pronunciation Challenges

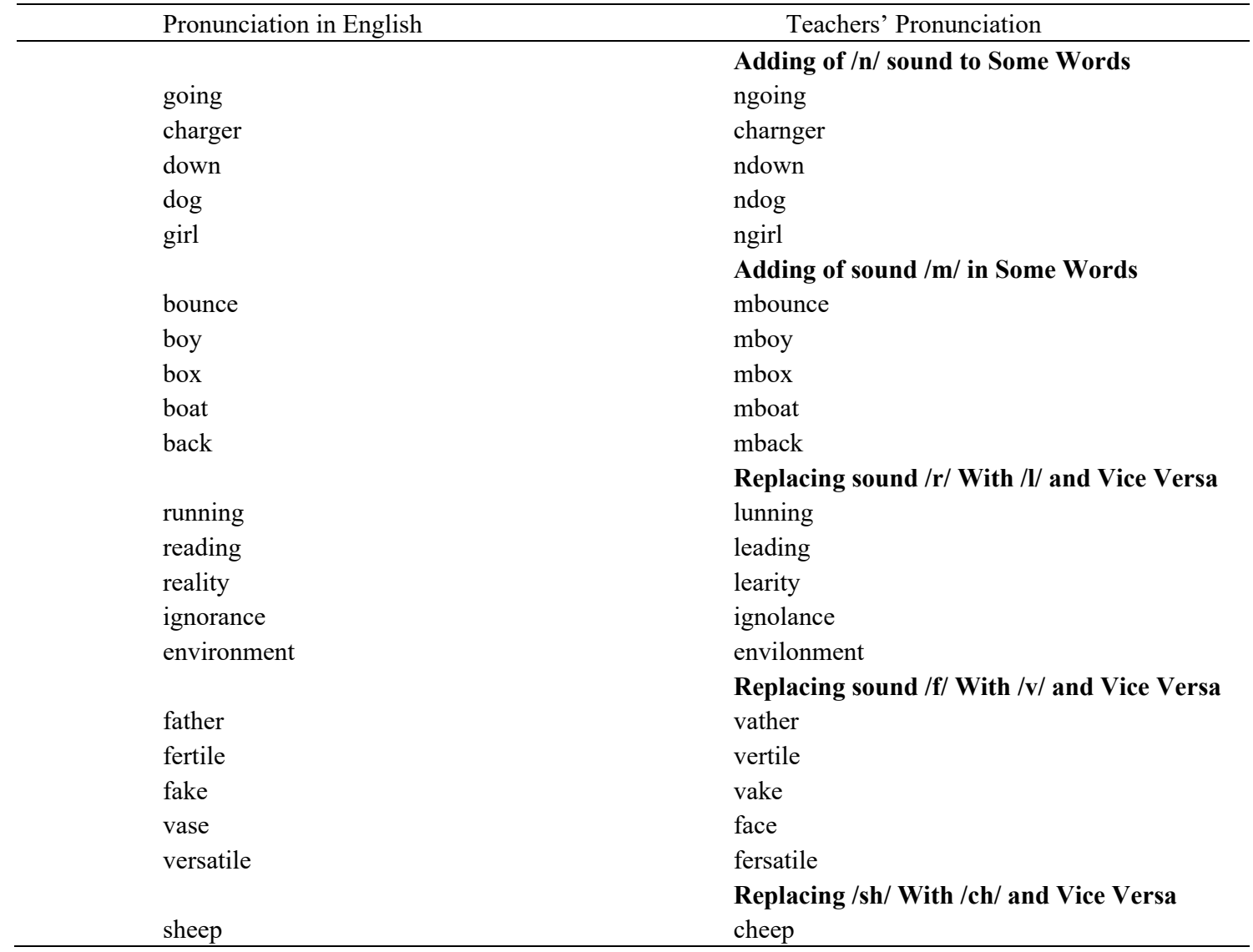




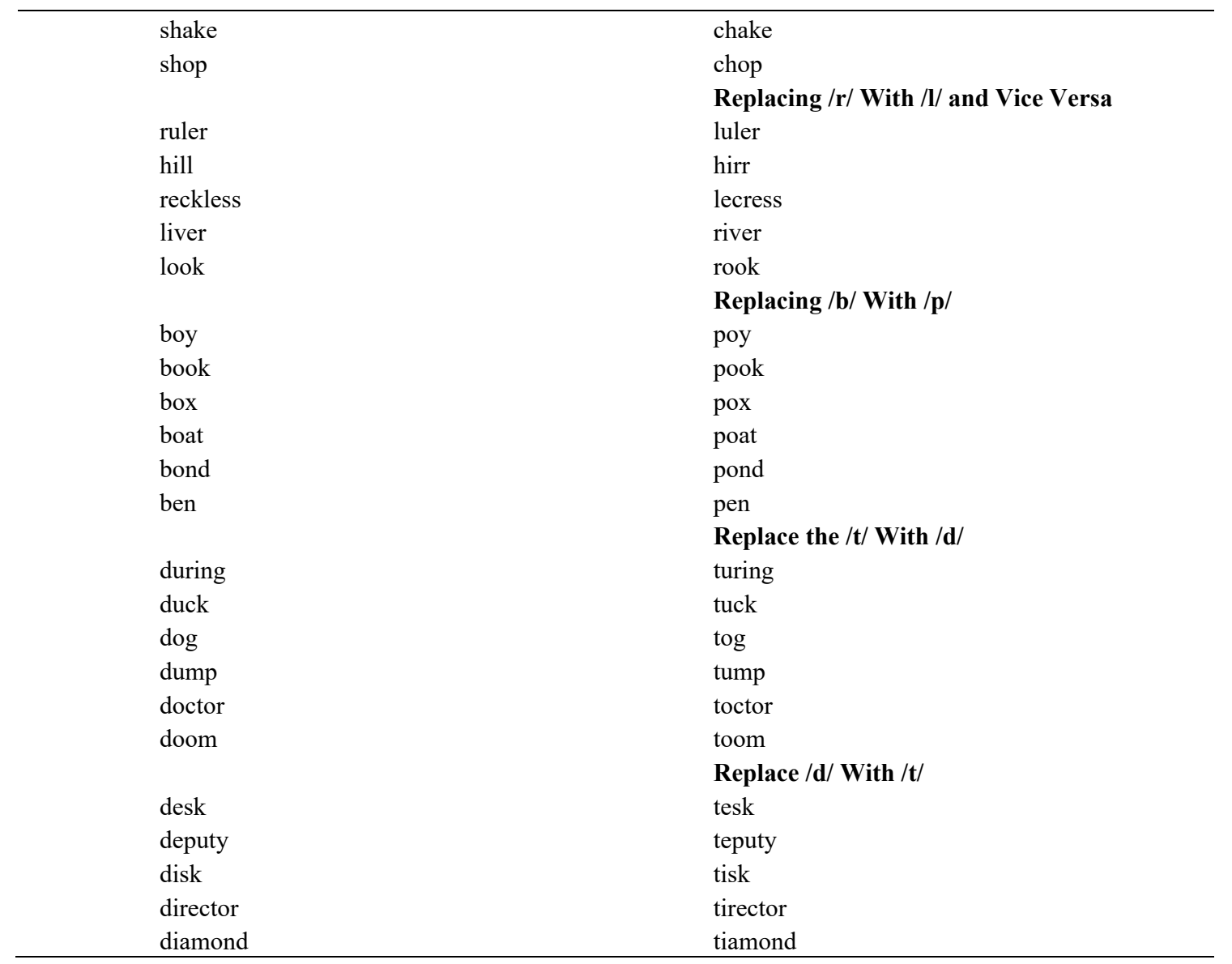

Tables 2 illustrates that some teachers of English do not meet the threshold of teaching English as a second language. They transfer errors to students because learners view them as role models. They also distort the meaning of the intended message, for example, instead of saying; Mary ate rice and liver, they say, Mary ate lice and river. Such statements are incomprehensible. In cases where there are no equivalent English words, one could approximate meaning, such as, pronouncing running as 'lunning.' When mispronunciation creates another English word, it distorts meaning completely; for example, the words in column A may be pronounced as the words in column B and vice versa.

A

$\begin{array}{ll}\text { Reading } & \text { leading } \\ \text { River } & \text { liver } \\ \text { Rice } & \text { lice } \\ \text { Vase } & \text { face } \\ \text { Shop } & \text { chop } \\ \text { Bond } & \text { pond }\end{array}$

\section{Conclusion}

Teachers of English were assumed to be role models in teaching pronunciation. They used imitation, phonetic transcriptions, minimal pair drills and sentence drills to teach pronunciation. It was established that some of them had pronunciation challenges affecting the intelligibility or comprehensibility of what they were communicating about. Comprehensible pronunciation is one of the necessary components of oral communication. Teachers of English lack teaching and learning resources such as tape recorders, language laboratories, and video recorders to improve teaching pronunciation yet they have challenges in pronunciation pedagogy. There is no need to achieve native like pronunciation, but it should not distort the meaning of what they are communicating. When a teacher who is meant to be a role model and source of input for learners uses incomprehensible pronunciation distorting meaning, it is a 
significant setback to English Language Teaching (ELT). There is need to reassess who should be trained to teach English in Kenya. Attaining a certain mean grade and score in the subject may not be enough. The communicative language teaching approach proposed to be used in ELT by the Kenya Institute of curriculum Development emphasizes that language is communication, therefore comprehensible pronunciation is important to facilitate the communication process both in the classroom and outside the classroom. Communication proficiency should be considered in English Language Teacher Education (ELTE) before admission of student teachers, their pronunciation should be comprehensible, not necessarily native like.

Institutions responsible for Curriculum Development should prepare and provide teaching and learning resources to teachers of English. The communicative language teaching approach recommended by language educators should be facilitated by using tape recordings, language laboratories, and video recordings among other resources to ensure learners involvement in varied language learning activities to minimize over reliance on teachers who may have pronunciation challenges.

\section{References}

Cele-Murcia, M., Brinton M. D., \& Godwin, M. J. (2007). Teaching Pronunciation. A Reference for Teachers of English to Speakers of other Languages. New York: Cambridge University Press.

Cohen, L., Manon, L., \& Morrison, K. (2007). Research Methods in Education (6th ed.). London: Routledge Flamer. https://doi.org/10.4324/9780203029053

Creswell, J. W. (2007). Research design qualitative, quantitative and mixed approaches (3rd ed.). London: Sage Publications limited.

Hammersiey, M., \& Atkinson, P. (2007). Ethnography: Principles in Practice (3rd ed.). London: Routledge. https://doi.org/10.4324/9780203944769

Jwan, J. O., \& Ong'ondo, C. O. (2011). Qualitative Research: An Introduction to Principles and Techniques. Eldoret: Moi University Press.

Kenya Institute of Education. (2002). Secondary Education syllabus (5th ed.). Nairobi: Kenya Literature Bureau.

Lichtman, M. (2006). Qualitative Research in Education: A user's guide. London: Sage Publications.

Marnie, R., \& Levis, J. (2015). The Handbook of English Pronunciation. Chichester, UK; Malden, MA: Wiley-Blackwell.

Pole, C., \& Morrison, M. (2003). Ethnography for education. Maidenhead: Open University Press.

Richards, J. C., \& Rodgers, T. (2001). Approaches and methods in language teaching (2nd ed.). Cambridge: Cambridge University Press. https://doi.org/10.1017/CBO9780511667305

Richards, K. (2009). Trends in Qualitative Research in Language Teaching Since 2000. Language Teaching, 42(2), 147-180. https://doi.org/10.1017/S0261444808005612

Stake, R. E. (2005). Qualitative Case Studies. In Denzin, N. K., \& Lincoln, Y. S. Sage Handbook of Qualitative research (3rd ed.). London: Sage Publications Limited, pp.443-4.

Yin, R. K. (2009). Case study research design and methods (3rd ed.). London: Sage Publications. 